\title{
Keanekaragaman Dan Distribusi Makroinvertebrata Di Perairan Hulu Tukad Cangkir Dan Tukad Pakerisan Kabupaten Gianyar
}

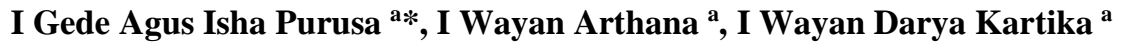 \\ ${ }^{a}$ Program Studi Manajemen Sumberdaya Perairan, Fakultas Kelautan dan Perikanan, Universitas Udayana, \\ Bukit Jimbaran, Bali-Indonesia \\ *Email: agusishapurusa@gmail.com
}

Diterima (received) 8 Januari 2020; disetujui (accepted) 30 Juni 2020; tersedia secara online (available online) 1 Agustus 2020

\begin{abstract}
Cangkir and Pakerisan are two rivers which are located in Gianyar-Bali Regency, each with a length of $23 \mathrm{~km}\left(54.58 \mathrm{~km}^{2}\right.$ of watershed area) and $34.5 \mathrm{~km}\left(58.33 \mathrm{~km}^{2}\right.$ of watershed area). These two rivers empties into Lebih Beach that each has a species diversity and abiotic factors. At the upstream of the rivers were occupied by tourism activities that can affect the ecosystem. This study aims to determine the diversity and distribution of macroinvertebrates in the two rivers. Sampling stations were situated at upstream area with 5 stations and 3 replications (15 points) on each river. Sample identification was carried out at the Laboratory of Water Resources Management, Faculty of Marine Science and Fisheries, Udayana University. It was found four species, namely Littorina carinifera, Melanoides torulosa, Parathelphusa convexa, and Bellamya javanica. At upstream of Cangkir and Pakerisan rivers had species of random category distribution pattern with the Morisita Distribution Index value that equal to one. Physical and chemical factors had a major influence on the ecological conditions of the two rivers. The environmental conditions that consisting of substrate type, several physical and chemical parameters were unable to support the life of various biota species found in these aquatic ecosystems.
\end{abstract}

Keywords: Bali rivers; diversity; Pakerisan; Cangkir; Substrate

\begin{abstract}
Abstrak
Tukad Cangkir dan Tukad Pakerisan merupakan dua sungai yang berada di Kabupaten Gianyar-Bali, dengan panjang masing-masing $23 \mathrm{~km}$ (luas DAS 54,58 km²) dan 34,5 km (luas DAS 58,33 $\mathrm{km}^{2}$ ). Kedua sungai ini bermuara di Pantai Lebih yang masing-masing memiliki keanekaragaman species dan faktor abiotik. Pada masing-masing hulu tukad tersebut terdapat aktivitas pariwisata yang dapat mempengaruhi ekosistemnya. Penelitian ini bertujuan untuk mengetahui keanekaragaman dan distribusi makroinvertebrata di kedua sungai. Stasiun pengambilan sampel terletak di bagian hulu masing-masing sungai sebanyak 5 stasiun dengan 3 ulangan (15 titik). Identifikasi sampel dilakukan di Laboratorium Manajemen Sumberdaya Perairan, Fakultas Kelautan dan Perikanan, Universitas Udayana. Makroinvertebrata yang teridentifikasi terdiri dari empat spesies yaitu Littorina carinifera, Melanoides torulosa, Parathelphusa convexa, dan Bellamya javanica. Hulu Tukad Cangkir dan Pakerisan memiliki tingkat pola sebaran spesies dengan distribusi kategori acak dengan nilai Indeks Penyebaran Morisita sama dengan satu. Faktor fisik dan kimia memiliki pengaruh yang besar terhadap kondisi ekologi perairannya. Kondisi lingkungan yang terdiri atas jenis substrat, beberapa parameter fisik dan kimia yang teranalisis tidak mampu menunjang kehidupan berbagai spesies biota yang terdapat pada ekosistem perairan tersebut.
\end{abstract}

Kata Kunci: Sungai Bali; diversitas; Pakerisan; Cangkir; Substrat

doi: https://doi.org/10.24843/blje.2020.v20.i02.p04

(C) 2019 by the authors; Content from this work may be used under the terms of the Creative Commons Attribution 3.0 licence. Any further distribution of this work must maintain attribution to the author(s) and the title of the work, journal citation and DOI. Published under licence by Udayana University, Indonesia. 


\section{Pendahuluan}

Perairan merupakan hal yang sangat penting dalam kehidupan makhluk hidup. Sungai adalah Salah satu perairan air tawar yang memiliki ekosistem yang sangat komplit dan dinamis dimana keberadaannya dipengaruhi oleh faktor biotik dan abiotik. Air sungai sebagai habitat air tawar membentuk ekosistem dengan beragam organisme yang hidup di dalamnya termasuk makroinvertebrate.

Hewan makroinvertebrata merupakan salah satu komponen penyusun ekosistem air tawar. Makroinvertebrata air merupakan komponen biotik pada ekosistem perairan yang dapat memberikan gambaran mengenai kondisi fisika, kimia, dan biologi suatu perairan sehingga digunakan sebagai indikator kualitas air sungai. Hal ini disebabkan adanya respon yang berbeda terhadap suatu bahan pencemar yang masuk dalam perairan sungai dan bersifat menetap dalam suatu perairan (Hynes, 1974; Hilsenshoff, 1977). Keberadaan bahan pencemar itu akan ikut mempengaruhi kondisi biotik dan abiotic suatu perairan.

Faktor biotik dan faktor abiotik sangat bervariasi antar ekosistem perairan yang membuat ekosistemekosistem tersebut memiliki karakteristik atau cirinya masing-masing. Keanekaragaman ekosistem merupakan suatu interaksi antara komunitas dan lingkungan abiotiknya pada suatu tempat dan waktu tertentu. Komunitas yang salah satunya makroinvertebrata merupakan, kumpulan populasi yang berinteraksi pada suatu tempat dan waktu tertentu (Mulyadi, A2010). Kelimpahan suatu organisme dapat berbeda di sepanjang aliran sungai, yang berarti bahwa beberapa jenis organisme hanya ditemukan di satu bagian sungai. Penyebaran yang berbeda ini sebagian besar ditentukan oleh faktor fisika-kimia seperti debit air, ukuran partikel di dasar, suhu, oksigen terlarut, zat hara mineral, arus dan jenis substrat (Michael, 1995).

Distribusi dan penyebaran suatu spesies seperti makroinvertebrate dalam ekosistem ditentukan oleh tingkat ketersediaan sumber daya serta kondisi faktor kimiawi dan fisis yang harus berada dalam kisaran yang dapat ditoleransi oleh spesies tersebut, inilah yang disebut dengan hukum toleransi. Dalam penyebarannya, individu-individu itu dapat berada dalam kelompok-kelompok, dan kelompok-kelompok itu terpisah antara satu dengan yang lain (Krebs, 1985).

Penyebaran makroinvertebrata dari suatu tempat ke tempat lainnya melintasi berbagai faktor penghalang. Faktor-faktor penghalang ini menjadi pengendali penyebaran organisme tersebut. Faktor penghalang yang utama adalah iklim dan topografi. Selain itu, faktor penghalang reproduksi dan endemisme menjadi pengendali penyebaran organisme. Akibat dari hal tersebut di atas adalah permukaan bumi ini terbentuk kelompok-kelompok hewan dan tumbuhan yang menempati daerah yang berbeda-beda.

Luas daerah yang dapat ditempati oleh makroinvertebrata berkaitan dengan kesempatan dan kemampuan mengadakan penyebaran seperti di sungai. Sungai merupakan jalan air alami yang mengalir menuju samudera, danau, laut, atau ke sungai yang lain. Sungai terdiri dari beberapa bagian yaitu bermula dari mata air yang mengalir ke anak sungai dimana kemudian beberapa anak sungai ini akan bergabung untuk membentuk sungai utama. Manfaat terbesar sebuah sungai disamping sebagai tempat hidup beragam biota seperti makroinvertebtara, adalah untuk irigasi pertanian, bahan baku air minum, sebagai saluran pembuangan air hujan dan air limbah, bahkan sebenarnya potensial untuk dijadikan objek wisata sungai (Herlambang, 2006). Untuk Bali, sungai-sungai semacam ini banyak jumlahnya yang dalam bahasa local disebut tukad.

Tukad Cangkir merupakan salah satu sungai yang berada di Kabupaten Gianyar, Bali. Tukad Cangkir memiliki panjang $23 \mathrm{~km}$ dan luas DAS 54,58 km2 (RKPD Kabupaten Gianyar, 2016). Selain Tukad Cangkir ada pula sungai yang berada di Kabupaten Gianyar yaitu Tukad Pakerisan. Tukad Pakerisan memiliki panjang 34,5 km, dan bermuara di Pantai Lebih (perbatasan Desa Medahan dan Desa Lebih), serta memiliki luas DAS 58,33 km2 (RKPD Kabupaten Gianyar, 2016). Pada masing - masing hulu tukad tersebut terdapat aktivitas pariwisata yang dapat mempengaruhi ekosistem kedua hulu tukad tersebut. Oleh karena itu, perlu adanya kajian tentang pengaruh aktivitas pariwisata terhadap keanekaragaman dan distribusi dari makroinvertebrata di Tukad Cangkir dan Tukad Pakerisan. 


\section{Metode Penelitian}

\subsection{Lokasi penelitian}

Lokasi pengambilan sampel dilakukan pada perairan hulu Tukad Cangkir dan Tukad Pakerisan, Kabupaten Gianyar. Pada masing-masing lokasi pengambilan sampel terdapat 5 stasiun yang telah ditentukan. Stasiun tersebut memiliki 15 titik yang tersebar di kawasan hulu sungai. Sampel yang didapatkan dari lokasi pengambilan, kemudian diidentifikasi di Laboratorium Manajemen Sumberdaya Perairan, Fakultas Kelautan dan Perikanan, Universitas Udayana. Peta penelitian dapat dilihat pada Gambar 1.

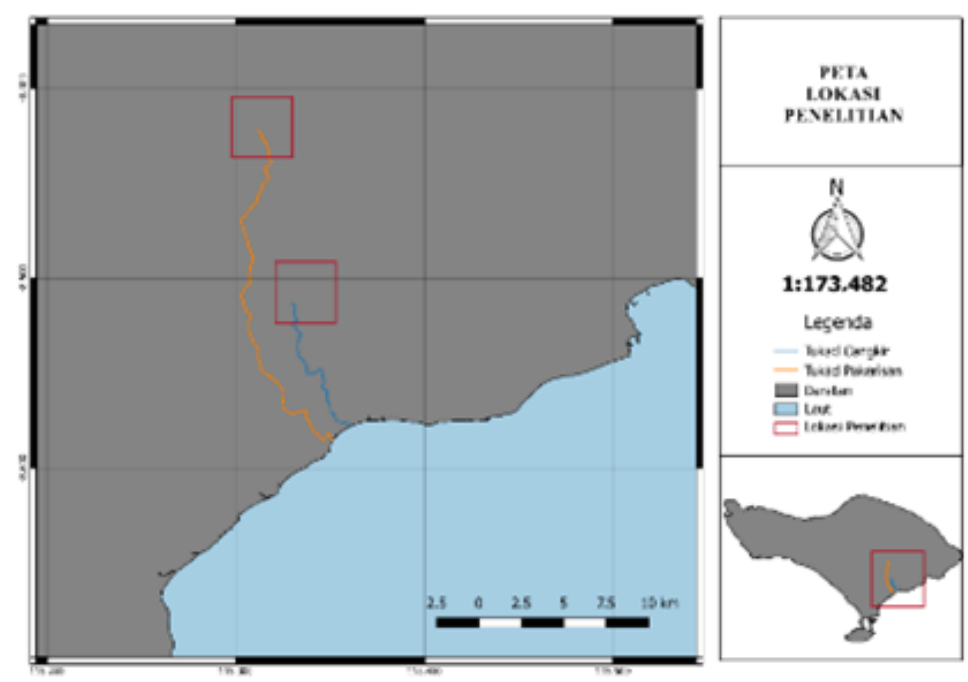

Gambar 1. Peta lokasi penelitian.

\subsection{Alat dan bahan}

Adapun alat dari penelitian makroinvertebrata meliputi surber bottle sample, tali rafia, buku identifikasi, plastik sample, alat tulis, kertas label, ember, global positioning system, kamera, kicknet $(0,05 \mathrm{~mm})$, tissue, dissecting set, cool box, $\mathrm{pH}$ meter, DO meter. Bahan dari penelitian makroinvertebrata meliputi alkohol $70 \%$, sampel makroinvertebrata, aquades.

\subsection{Metode penelitian}

Penelitian ini menggunakan metode deskriptif kuantitatif.

\subsubsection{Metode pengambilan sample}

Pada Pengambilan sampel makroinvertebrata metode yang digunakan yaitu metode kuadrat. Alat yang digunakan saat pengambilan sampel makroinvertebrata yaitu Surber Bottom Sampler dan dilakukan secara manual. Pada setiap stasiun terdapat 3 titik pengambilan sampel yang berjarak sesuai dengan lebar sungai tersebut. Lebar sungai dilakukan pengukuran sebelum pengambilan sampel makroinvertebrata dilakukan. Pengukuran dilakukan dengan menggunakan tali rafia yang sudah disediakan sebelumnya. sampel yang didapatkan dari Surber Bottom Sampler berupa hewan makroinvertebrata yang diambil menggunakan tangan dan yang berada di permukaan air akan masuk ke dalam net pada alat Surber Bottom Sampler. Makroinvertebrata yang telah didapatkan ditampung pada ember. Makroinvertebrata yang telah ditampung dalam ember selanjutnya dimasukkan ke dalam plastik sampel kemudian diberi 
alkohol 70\%. Setelah dimasukkan ke dalam plastik sampel selanjutnya akan diisi label sesuai titik pengambilan. Identifikasi makroinvertebra yang telah didapatkan dilokasi penelitian dilakukan di laboratorium manajemen sumberdaya perairan.

\subsubsection{Pengukuran kualitas perairan}

Pada pengukuran kualitas air dilakukan dengan cara in situ dan dilakukan bersamaan dengan pengambilan sampel makroinvertebrata. Pengukuran kualitas air dilakukan 2 minggu sekali dengan pengulangan 3 kali di setiap tempat penelitian. Adapun kualitas air yang diukur yaitu suhu, $\mathrm{pH}$, oksigen terlarut (DO), dan substrat. Pengambilan Data Sampel Makroinvertebrata.

\subsection{Analisis data}

\subsubsection{Indeks keanekaragaman}

Indeks keanekaragaman makrozoobentos dihitung dengan menggunakan formula Evennes Indeks (Odum, 1971) sebagai berikut:

$$
H^{\prime}=-\sum \frac{n_{i}}{N} \times \frac{L n_{n_{i}}}{N}
$$

dimana $\boldsymbol{H}^{\prime}$ adalah indeks keanekaragaman jenis; $\boldsymbol{n}_{\boldsymbol{i}}$ adalah jumlah individu setiap jenis; $\boldsymbol{N}$ adalah jumlah seluruh individu. Indeks keanekaragaman yang didapatkan kemudian dimasukkan dalam kriteria keanekaragaman sebagai berikut: (Krebs, 1985 dalam Fitra, 2008) dimana $\boldsymbol{H}^{\prime}$ bernilai $0-2,302$ merupakan keanekaragaman rendah; $\boldsymbol{H}^{\prime}$ 'bernilai 2,302 - 6,907 merupakan keanekaragaman sedang; $\boldsymbol{H}^{\prime}$ lebih besar dari 6,907 merupakan keanekaragaman tinggi.

\subsubsection{Distribusi}

Untuk mengetahui Distribusi makroinvertebrata ditentukan dengan menggunakan rumus Indeks Penyebaran Morisita (Khouw, 2009) yakni:

$$
I d=n\left[\frac{\sum x^{2}-\sum x}{\left(\sum x\right)^{2}-\sum x}\right]
$$

Dimana $\boldsymbol{I} \boldsymbol{d}$ adalah Indeks Penyebaran Morisita; $\mathrm{n}$ adalah Jumlah plot / besar sampel; $\boldsymbol{\Sigma} \boldsymbol{x}$ adalah Jumlah Individu di setiap plot; $\Sigma \boldsymbol{x}^{2}$ adalah Jumlah individu di setiap plot yang dikuadratkan. Kriteria pola sebaran sebagai berikut dimana Id sama dengan 1, maka distribusi populasi kategori acak; Id lebih dari 1, maka distribusi populasi kategori bergerombol/mengelompok; Id kurang dari 1, maka distribusi populasi kategori seragam.

\subsubsection{Indeks keseragaman}

Rumus dari indeks keseragaman Pielou (E) menurut Pielou (1966) dalam Odum (1983), yaitu sebagai berikut:

$$
E=\frac{H^{\prime}}{\ln S}
$$

Dimana E adalah Indeks Keseragaman; H' adalah Indeks Keanekaragaman; S adalah Jumlah spesies. 


\section{Hasil dan Pembahasan}

\subsection{Keanekaragaman Makroinvertebrata}

Pada stasiun Hulu Tukad Cangkir nilai indeks kenaekaragaman tertinggi berada di stasiun 1 yaitu 0,85. Sedangkan nilai indeks keanekaragaman pada Hulu Tukad Pakerisan yang tertinggi terdapat pada stasiun 2 yaitu 0,78. Tingkat keanekaragaman pada kedua lokasi penelitian tersebut tergolong rendah karena memiliki nilai keanekaragaman $\left(H^{\prime}\right)$ pada kisaran $0-2,302$ dimana menurut indek kenanekaragaman dari Krebs, 1985 dalam Fitra, 2008 termasuk dalam kriteria keanekaragaman rendah. Keanekaragaman yang rendah menunjukkan kuantitas jenis dan jumlah organisme yang ditemukan disuatu habitat sangat minim, sehingga memberikan gambaran kondisi ekologis perairan yang tidak stabil (Doods, 2002). Pada indek keanekaragaman kedua lokasi penelitian memiliki nilai kenaekaragaman kurang dari satu dan di lokasi penelitian Hulu Tukad Pakerisan spesies Bellamya javanica tidak ditemukan yang kemungkinan diakibatkan oleh kemampuan adaptasi yang dimiliki masing-masing jenis terhadap kondisi lingkungan sekitar.

Selain itu faktor ketersediaan makanan juga ikut berpengaruh dalam menunjang keberlangsungan hidup dan pertumbuhan Bellamya javanica (Siregar, 2013). Dengan berkurangnya ketersediaan makanan untuk spesies Bellamya javanica maka dari itu tidak ditemukannya spesies tersebut pada lokasi penelitian Hulu Tukad Pakerisan. Indeks keanekaragaman kedua lokasi penelitian dapan dilihat pada Gambar 2.

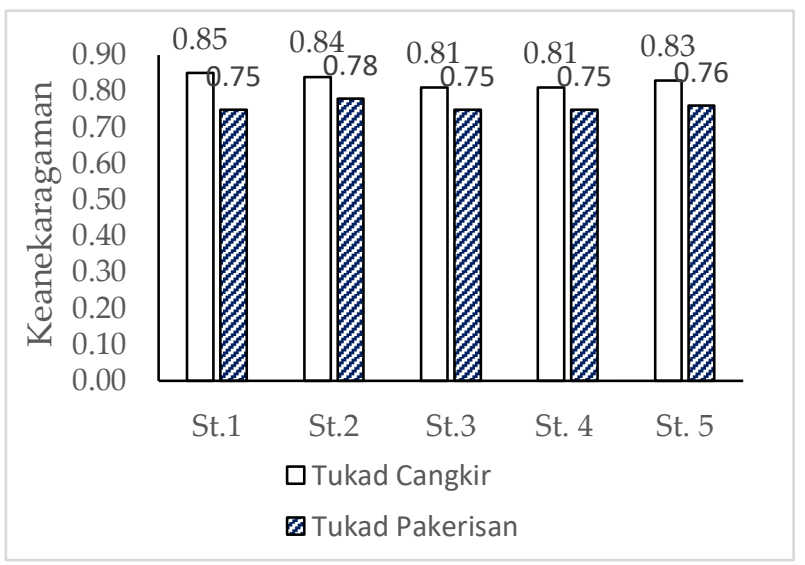

Gambar 2. Indeks keanekaragaman di kedua lokasi penelitian.

\subsection{Distribusi Makroinvertebrata}

Hasil indeks distribusi makroinvertebrata pada perairan Hulu Tukad Cangkir dan Hulu Tukad Pakerisan berkisar 0,1 - 1,04. Pada lokasi penelitian Hulu Tukad Pakerisan tidak terdapatnya Bellamya javanica dan mendominasinya spesies Littorina carinifera dan Parathelphusa convexsa pada Hulu Tukad Cangkir dibandingkan di Hulu Tukad Pakerisan ada beberapa faktor yg mempengaruhi keberadaan nya pada ekosistem sungai diantaranya yaitu faktor sumber makanan yang terdapat pada habitatnya. Berdasarkan indek penyebaran morisita (Khouw, 2009) pada Hulu Tukad Cangkir memiliki tingkat pola sebaran distribusi kategori acak karena nilai indeks penyebaran morisita sama dengan satu, sedangkan di Hulu Tukad Pakerisan memiliki pola sebaran distribusi yang sama yaitu kategori acak karena nilai indeks penyebaran morisita sama dengan satu. Sihombing dkk (2013) menyatakan bahwa terjadinya pola secara acak terhadap individu dapat disebabkan oleh populasi itu memberikan respon yang berbeda pada suatu kondisi lokal yang baik untuk kelangsungan hidupnya, sehingga akan mempengaruhi keanekaragaman dan distribusi suatu populasi. Penyebaran populasi dapat disebabkan karena dorongan mencari makan, menghindarkan diri dari predator, pengaruh iklim, terbawa air atau angin, perilaku kawin atau faktor fisik lainnya (Sura, 2013). Distribusi kedua lokasi penelitian dapat dilihat pada Gambar 3. 


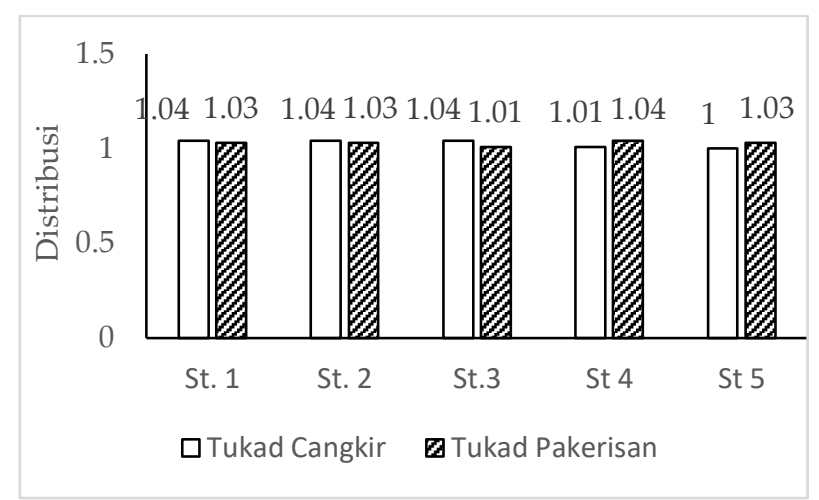

Gambar 3. Distribusi di kedua lokasi penelitian.

\subsection{Faktor Fisik dan Kimia Perairan}

Hasil rata rata pengukuran suhu \pm standar deviasi pada lokasi penelitian Hulu Tukad Cangkir dan Hulu Tukad Pakerisan berkisar antara 25,23 - 25,83 \pm 0,06 - 0,15 yang menunjukkan suhu yang cukup baik. Menurut Andriana, 2008 suhu $36,5^{\circ} \mathrm{C}-41^{\circ} \mathrm{C}$ merupakan temperatur lethal bagi makroinvertebrata artinya pada suhu tersebut organisme tersebut telah mencapai titik kritis yang dapat menyebabkan kematian. Keanekaragaman suatu perairan cenderung rendah dalam ekosistem yang mengalami tekanan secara fisik dan kimia (Odum, 1994). Hasil pengukuran suhu dapat dilihat pada gambar 4.

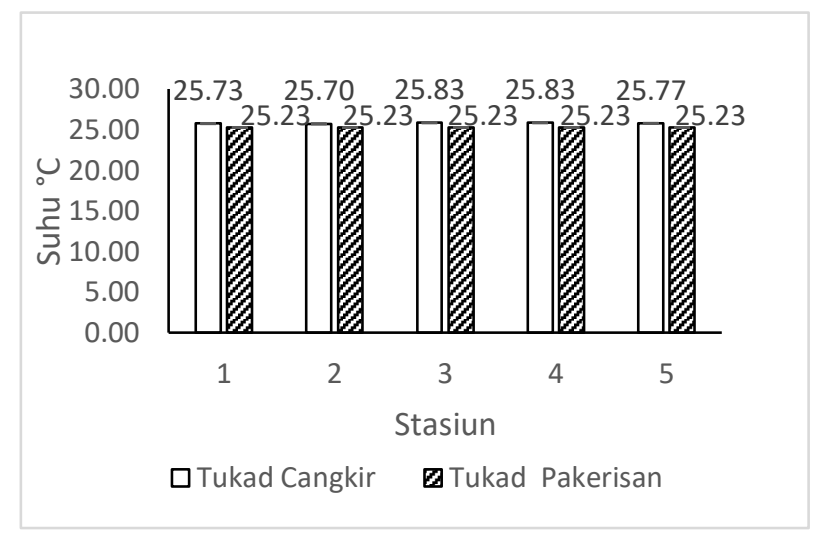

Gambar 4. Hasil pengukuran suhu di kedua lokasi penelitian.

Kisaran rata - rata nilai $\mathrm{pH} \pm$ standar deviasi perairan di Hulu Tukad Cangkir antara 7,73 - 7,93 \pm 0,06 dan rata - rata $\mathrm{pH} \pm$ standar deviasi perairan di Hulu Tukad Pakerisan antara 7,63 - 7,93 \pm 0,06. Nilai pH yang ideal bagi kehidupan biota air tawar adalah antara 6,8 - 8,5 (Welch, 1980). Perairan pada $\mathrm{pH}$ yang sangat rendah, menyebabkan kelarutan logam-logam dalam air makin besar, yang bersifat toksik bagi organisme air, sebaliknya $\mathrm{pH}$ yang tinggi dapat meningkatkan konsentrasi amoniak dalam air yang juga bersifat toksik bagi organisme air. Hasil pengukuran $\mathrm{pH}$ dapat dilihat pada gambar 5 . 


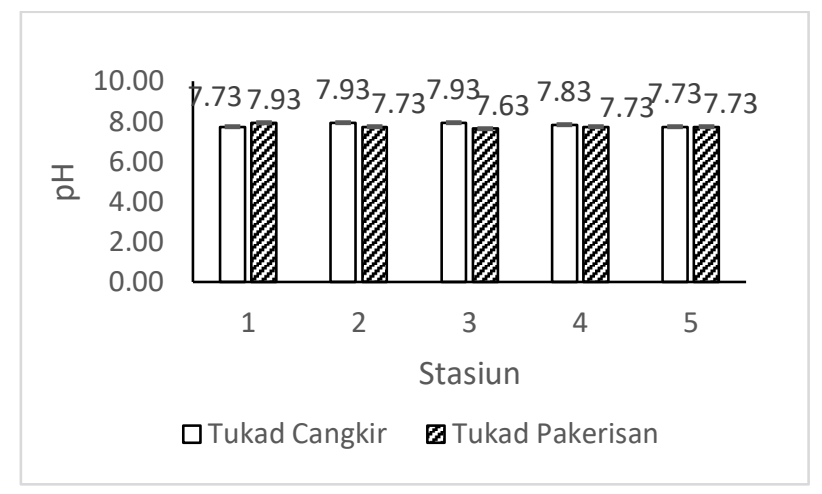

Gambar 5. Hasil pengukuran pH di kedua lokasi penelitian

Berdasarkan pengukuran pada perairan Hulu Tukad Cangkir dan Tukad Pakerisan rata - rata oksigen terlarut \pm standar deviasi berkisar antara 7,13-7,19 Mg/L $\pm 0,06$. Pada perairan DO dibutuhkan oleh semua jasad hidup untuk pernafasan, proses metabolisme atau pertukaran zat yang kemudian menghasilkan energi untuk pertumbuhan dan pembiakkan. Disamping itu, oksigen juga dibutuhkan untuk oksidasi bahan - bahan organik dan anorganik dalam proses aerobik. Sumber utama oksigen dalam suatu perairan berasal dari suatu proses difusi dari udara bebas dan hasil fotosintesis organisme yang hidup dalam perairan tersebut. Kecepatan difusi oksigen dari udara, tergantung dari beberapa faktor, seperti kekeruhan air, suhu, salinitas, pergerakkan massa air dan udara seperti arus, gelombang dan pasang surut (Effendi, 2003). Hasil pengukuran oksigen (DO) terlarut dapat dilihat pada gambar 6.

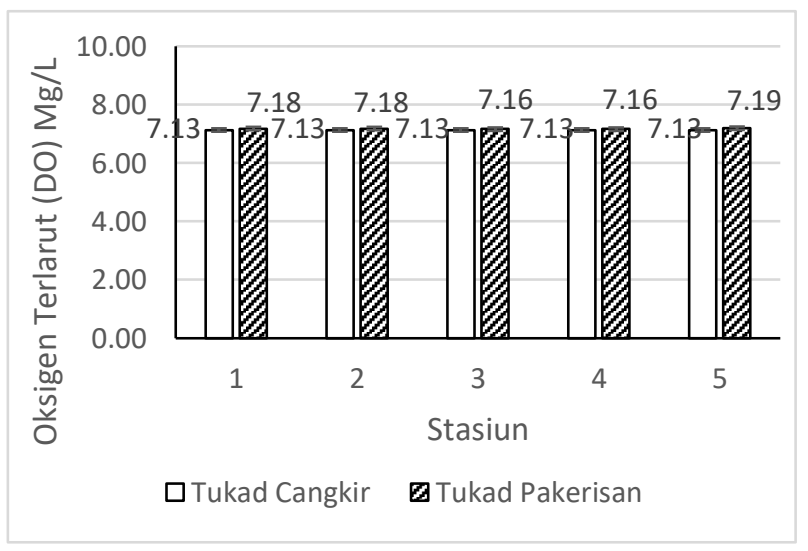

Gambar 6. Hasil pengukuran Oksigen Terlarut (DO) di kedua lokasi penelitian

Pada lokasi penelitian Hulu Tukad Cangkir dan Tukad Pakerisan memiliki substrat yang sama yaitu berbatu. Substrat merupakan komponen yang sangat penting bagi kehidupan organisme (Susanto, 2000). Karakteristik substrat dapat mempengaruhi struktur komunitas di Hulu Tukad Cangkir dan Tukad Pakerisan. Jika substrat mengalami perubahan maka struktur komunitas akan mengalami perubahan pula. Substrat berbatu dan berpasir cenderung memudahkan untuk bergeser dan bergerak ke tempat lain sedangkan substrat lumpur biasanya mengandung sedikit oksigen dan organisme yang hidup di dalamnya harus dapat beradaptasi pada keadaan tersebut (Ramli, 1989).

Dalam penelitian yang dilakukan di Hulu Tukad Cangkir dan Tukad Pakerisan masuknya bahan organik ke dalam perairan sedikit kurang sebab hanya beberapa titik yang terdapat sumber dari bahan organik tersebut yang dapat dilihat kurangnya persebaran makroinvertebrata di lokasi penelitian. Menurut Nurracmi dan Marwan (2012) menyatakan bahwa hewan benthos atau makroinvertebrata erat kaitannya 
dengan tersedianya bahan organik yang terkandung dalam substrat maupun di luar substrat, karena bahan organik merupakan sumber nutrien bagi biota yang pada umumnya terdapat pada substrat dasar.

\section{Simpulan}

Ada empat spesies makroinvertebrata yang ditemukan yaitu Littorina carinifera, Melanoides torulosa, Parathelphusa convexa, Bellamya javanica tetapi spesies Bellamya javanica pada lokasi penelitian di Hulu Tukad Pakerisan tidak ditemukan. Makroinvertebtara di hulu Tukad Cangkir memiliki tingkat pola sebaran distribusi kategori acak dengan nilai indeks penyebaran morisita sama dengan satu. Pola distribusi tersebut dapat menunjukkan bahwa ekosistem sungai tersebut tergolong seimbang. Kondisi parameter fisik dan kimia di kedua lokasi penelitian termasuk dalam keadaan ideal untuk kehidupan makroinvertebrata.

\section{Daftar Pustaka}

[RKPD] Rencana Kerja Pembangunan Daerah Kabupaten Gianyar. 2015. Peraturan Bupati Gianyar No 49 Tahun 2015. Pemerintah Kabupaten Gianyar. hlm 6.

Adriana, W. 2008. Keterkaitan Struktur Komunitas Makrozoobenthos Sebagai Indikator Keberadaan Bahan Organik Di Perairan Hulu Sungai Cisadane, Bogor. Jawa Barat. Fakultas Perikanan dan Ilmu Kelautan. IPB: Bogor. hlm 54.

Dodds, K. W. 2002. Freshwater Ecology Concepts and Eviromental Applications. Academic Press. San Diego California. hlm 998.

Effendi, H. 2003. Telaah Kualitas Air bagi Pengelolaan Sumberdaya dan Lingkungan Perairan. Penerbit Kanisius, Yogyakarta. hlm 249.

Herlambang, Arie. 2006. Pencemaran Air Dan Strategi Penanggulangannya. Jurnal Air Indonesia 2(1):16-29.

Hynes, HBN. (1976). The Ecology with of Running Water. Livervool University Press, England. hlm 555.

Khouw, A. S. 2009. Metode dan Analisa Kuantitatif dalam Bioekologi Laut. Pusat Pembelajaran Pengembangan Pesisir dan Laut. Jakarta. hlm 285.

Krebs, C. J. 1985. Experimental Analysis of Distribution of Abudance. Third edition. Newyork: Haper \& Row Publisher. hlm 678.

Michael, P. (1995). Metoda Ekologi Untuk Penyelidikan Lapangan dan Laboratorium. Universitas Indonesia Press, Jakarta. hlm 610 - 616.

Mulyadi, A. (2010). Pengetahuan Lingkungan Hidup. Bandung: Prisma Press. hlm 1.

NurrachmiI, Marwan. 2012. Kandungan Bahan Organik Sedimen dan Kelimpahan Makrozoobenthos sebagai Indikator Pencemaran Perairan Pantai Tanjung Uban Kepulauan Riau. LIPI. Universitas Riau. Pekanbaru.

Odum, E. P., 1971. Dasar-Dasar Ekologi, Edisi ketiga. Yogyakarta: Gadjah Mada University Press. hlm 697.

Odum, E. P., 1983. Dasar-Dasar Ekologi, Edisi ketiga. Gadjah Mada University Press Yogyakarta. hlm 697.

Odum, E.P. 1994. Dasar-dasar Ekologi. Edisi Ketiga. Universitas Gadjah Mada Press, Yogyakarta (Penerjemah Tjahjono Samingar). hlm 697.

Putra, I. P. (2014). Kajian Kerapatan Lamun terhadap Kepadatan Siput Gonggong (Strombus canarium) di Peraiaran Pulau Penyengat Kepulauan Riau. Kelautan dan Perikanan, 3(12), 25-67.

Ramli, D. 1989. Ekologi. Jakarta: Departemen Pendidikan dan Kebudayaan. hlm 268. 
Riniatsih, I., Hartati, R., Rejeki, S., \& Endrawati, H. (2018). Studi Keanekaragaman Makrozoobentos Pada Habitat Lamun Hasil Transplantasi dengan Metode Ramah Lingkungan. Jurnal Kelautan Tropis, 21(1), 29-36.

Robin, A. (2008). Encyclopedia of marine gastropods. Germany: ConchBooks

Shannon, C. E. \& Wiener, W. (1963). The mathematical theory of communication. Urbana, USA: University Illinois Press.

Sura', S. A. 2013. Pola Penyebaran Individu Dalam Populasi. Retrieved 24 Mei 2019, from Nortoks Arief_Soera: http://nartoksarif.blogspot.co.id/2013/05/pola-penyebaran-individu dalampopulasi.html

Sihombing, B., Nasution Syafruddin, Efriyeldi. 2013. Distribusi Kelimpahan Gastropoda (Telescopium Telescopium) di Ekosistem Mangrove Muara Sungai Dumai. Sumatera. Fakultas Perikanan dan Ilmu Kelautan Universitas Riau, Pekanbaru. hlm 10.

Siregar, NMA. (2013). Analisis Kandungan Logam Berat Pb dan Cd pada Keong Tutut (Bellamya javanica v.d Bush 1844) di Waduk Saguling, Jawa Barat. Skripsi. Institut Pertanian Bogor. Bogor. hlm 20.

Sukawati, N. K. A., Restu, I. W., \& Saraswati, S. A. (2018). Sebaran dan Struktur Komunitas Moluska di Pantai Mertasari Kota Denpasar, Provinsi Bali. Journal of Marine and Aquatic Sciences, 4(1), 78-85.

Susanto, P. 2000. Pengantar Ekologi Hewan. Jakarta: Proyek Pengembangan Guru Sekolah Menengah IBRD Loan No. 3979 Direktorat Jenderal Pendidikan Tinggi Departemen Pendidikan Nasional.

Terinbali. (2015). Sebaran dan Keragaman Makrozoobentos serta Keterkaitannya dengan Komunitas Lamun di Calon Kawasan Konservasi Perairan Daerah (Kkpd) di Perairan Kabupaten Luwu Utara. Skripsi. Makassar, Indonesia: Jurusan Ilmu Kelautan, Fakultas Ilmu Kelautan dan Perikanan Universitas Hasanuddin.

Wahab, I., Kawaroe, M., \& Madduppa, H. (2018). Perbandingan Kelimpahan Makrozoobentos di Ekosistem Lamun pada Saat Bulan Purnama dan Perbani di Pulau Panggang Kepulauan Seribu Jakarta. Jurnal Ilmu dan Teknologi Kelautan Tropis, 10(1), 217-229.

Welch, P. S. 1980. Limnology 2nd edition. Mc Hill Book. New York. hlm 15-17.

Odum, E. P. (1993). Dasar-Dasar Ekologi. (3rd ed). Yogyakarta, Indonesia: Gadjah Mada University press.

Woodburry, G. (2002). Introduction to statistic. Canada: Duxbury. 